\title{
Efektivitas Pemberian Edukasi secara Online melalui Media Video dan Leaflet terhadap Tingkat Pengetahuan Pencegahan Covid-19 di Kota Baubau
}

\section{The Effectivity of Providing Online Education through Video and Leaflet Media on the Knowledge Level of Covid-19 Prevention at Baubau City}

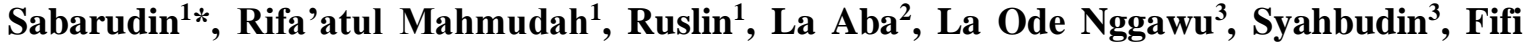 \\ Nirmala $^{4}$, Atika Indra Saputri ${ }^{4}$, Muhammad Syawal Hasyim ${ }^{1}$ \\ ${ }^{1}$ Jurusan Farmasi, Fakultas Farmasi, Universitas Halu Oleo, Kendari, Indonesia \\ ${ }^{2}$ Fakultas MIPA, Universitas Halu Oleo, Kendari, Indonesia \\ ${ }^{3}$ Fakultas Keguruan dan Ilmu Pendidikan, Universitas Halu Oleo, Kendari, Indonesia \\ ${ }^{4}$ Jurusan Kesehatan Masyarakat, Fakultas Kesehatan Masyarakat, Universitas Halu Oleo, Kendari, Indonesia \\ *Email: andres_sabar@yahoo.com
}

\section{Article Info:}

Received: 15 Agustus 2020

in revised form: 21 Agustus 2020

Accepted: 28 September 2020

Available Online: 30 September 2020

\begin{tabular}{l} 
Keywords: \\
Knowledge \\
Educational media \\
Prevention \\
Covid-19 \\
\hline Corresponding Author: \\
Sabarudin \\
Jurusan Farmasi \\
Fakultas MIPA \\
Universitas Halu Oleo \\
Kendari \\
93232 \\
Indonesia \\
email: andres_sabar@yahoo.com
\end{tabular}

Keywords:

Knowledge

Prevention

Covid-19

Corresponding Author:

Kendari

email:andres_sabar@yahoo.com

\begin{abstract}
Covid-19 is an infectious disease caused by acute respiratory syndrome coronavirus 2 (severe acute respiratory syndrome coronavirus 2 or SARS CoV-2). As of June 30, 2020, 216 countries in the world have been confirmed to have Covid-19 with a positive number of 10,117,687 and have died 502,278. Southeast Sulawesi in particular has been confirmed as of June 30, 2020, as many as 363 positive cases, 234 recovered, and 6 deaths. Meanwhile, in Baubau, there were 20 positive confirmed cases. Compliance with health protocols is believed to prevent transmission of Covid-19. Increasing knowledge through education is one of the methods used to increase compliance. This study aims to determine the effectiveness of Covid-19 prevention education through video media and online leaflets on the level of public knowledge at Baubau City. This study used a Quasi-Experiment with the approach method of The NonRandomized Without Control Group Pretest and Posttest Design. The population is all people of Baubau City with an affordable population during the Covid-19 pandemic based on 1,600 Whatsapp group participants with a sample size of 120 people. The sampling technique used a purposive sampling method that met certain criteria. Based on the results of statistical tests with Wilcoxon, the value on the use of video media \& leaflets was obtained $\mathrm{P}=0.001<0.05$, this indicates that there is a significant difference in knowledge before and after online education. On video media $\mathrm{P}=0.248>0.05$ showed that there is no significant difference after online education. Whereas in the media leaflet $\mathrm{P}=0.045<0.05$ indicated that there is a significant difference after online education. In this study, video media \& leaflets and leaflet media are more effectively used as education on prevention of COVID19 online compared to video media alone.
\end{abstract}

Copyright $\odot 2019$ JFG-UNTAD This open access article is distributed under a Creative Commons Attribution (CC-BY-NC-SA) 4.0 International license. How to cite (APA $6^{\text {th }}$ Style):

Sabarudin, Mahmudah, R., Ruslin., Aba, L., Nggawu, L, O., Syahbudin., Nirmala, F., Saputri, A, I., \& Hasyim, M, S. (2020). Efektivitas Pemberian Edukasi secara Online melalui Media Video dan Leaflet terhadap Tingkat Pengetahuan Pencegahan Covid-19 di Kota Baubau. Jurnal Farmasi Galenika :Galenika Journal of Pharmacy (e-Journal), 6(2), 309318. doi: $10.22487 / \mathrm{j} 24428744.2020 . v 6.12 .15253$ 


\section{ABSTRAK}

Covid-19 merupakan penyakit menular yang disebabkan oleh sindrom pernapasan akut coronavirus 2 (servere acute respiratory syndrome coronavirus 2 atau SARS-coV-2). Pada tanggal 30 Juni 2020 terdapat 216 negara di dunia yang sudah terkonfirmasi terkena Covid-19 dengan angka positif 10.117.687 dan meninggal 502.278. Sulawesi Tenggara khususnya telah terkonfirmasi sampai dengan 30 Juni 2020 sebanyak 363 kasus positif, sembuh sebanyak 234, dan meninggal sebanyak 6. Sedangkan di Kota Baubau, kasus konfirmasi positif sebanyak 20 orang. Kepatuhan terhadap protokol kesehatan diyakini dapat mencegah penularan Covid-19. Peningkatan pengetahuan melalui edukasi adalah salah satu metode yang digunakan untuk meningkatkan kepatuhan. Penelitian ini bertujuan untuk mengetahui efektivitas pemberian edukasi secara online melalui media video dan leaflet terhadap tingkat pengetahuan pencegahan Covid-19 masyarakat di Kota Baubau. Penelitian ini menggunakan metode Quasi-Experiment dengan pendekatan The Non-Randomized Without Control Group Pretest And Posttest Design. Populasi adalah seluruh masyarakat Kota Baubau dengan populasi terjangkau di masa pandemi Covid-19 berdasarkan peserta group Whatsapp sebanyak 1600 orang dengan jumlah sampel 120 orang. Teknik pengambilan sampel menggunakan metode purposive sampling yang memenuhi kriteria tertentu. Berdasarkan hasi uji statistik dengan wilcoxon diperoleh nilai pada penggunaan media video \& leaflet $\mathrm{P}=0,001<0,05$, hal ini menunjukkan bahwa terdapat perbedaan bermakna pengetahuan sebelum dan setelah edukasi secara online. Pada media video $\mathrm{P}=0,248>$ 0,05, hal ini menunjukkan tidak ada perbedaan bermakna setelah edukasi secara online. Sedangkan pada media leaflet $\mathrm{P}=0,045<0,05$, hal ini menunjukkan ada perbedaan bermakna setelah edukasi secara online. Pada penelitian ini media video \& leaflet serta media leaflet lebih efektif digunakan sebagai edukasi pencegahan COVID-19 secara online dibandingkan media video saja.

Kata kunci: Pengetahuan, Edukasi, Pencegahan, Covid-19

\section{PENDAHULUAN}

Covid-19 merupakan penyakit menular yang pertama kali ditemukan di wuhan, hubei, china pada akhir tahun 2019. Virus ini sering ditemukan pada hewan, yang masih dalam bagian corona virus. Ketika menyerang manusia corona virus biasanya menyebabkan penyakit infeksi saluran pernapasan, seperti flu. MERS (Middle East Respiratory Syndrome) dan SARS (Servere Acute Respratory Syndrome) (Hui et al., 2020). Gejala yang umumnya ditemukan pada penderita covid19 seperti demam, batuk kering dan kesulitan bernapas (Chen et al., 2020)(Hessen, 2020). Sedangkan sakit tenggorokan, pilek atau bersin lebih jarang ditemukan (Huang et al., 2020). Kemungkinan terburuk dari penyakit ini adalah pneumonia dan kegagalan multiorgan (Hui et al., 2020)(Chen et al., 2020).

Coronavirus jenis baru atau dikenal dengan Covid-19 telah mengakibatkan wabah pneumonia yang sangat viral di China (Li et al., 2020). 30 hari setelah kasus pertama diumumkan, pada 29 Januari 2020 telah terkonfirmasi kasus baru Covid-19 sebanyak 6.065 dan telah menyebar ke beberapa negara, terutama di Cina, dimana dilaporkan sebanyak 1.239 kasus parah dan 132 kasus kematian. Pada saat itu, hanya 68 kasus yang telah diidentifikasi di 15 negara di luar daratan Cina, yang semuanya memiliki kaitan dengan Cina atau dengan kasus-kasus dari Cina (World Health Organization, 2020). Tak hanya Penularan dari orang ke orang yang telah mengalami gejala, virus ini juga dapat ditransmisikan oleh pembawa asimptomatik (Yan Bai \& Lingsheng Yao, 2020).

Pada tanggal 30 Juni 2020 terdapat 216 negara di dunia yang sudah terkonfirmasi terkena Covid19 dengan angka positif 10.117.687 dan meninggal 502.278. Di Indonesia, kasus positif berjumlah 56.385, sembuh berjumlah 24.806 dan meninggal berjumlah 2.876 (COVID-19, 2020). Berdasarkan data yang diperoleh dari akun instagram satgascovid19.sultra, kasus konfirmasi positif sebanyak 363, sembuh sebanyak 234 , dan meninggal sebanyak 6. Sedangkan di Kota Baubau, kasus yang terkonfirmasi positif adalah sebanyak 20 orang (satgas covid sultra, 2020). jumlah ini diprediksi akan terus bertambah seiring dengan kurangnya pengetahuan masyarakat terhadap tindakan pencegahan Covid-19 di Kota Baubau.

Pengetahuan tentang penyakit Covid-19 merupakan hal yang sangat penting agar tidak menimbulkan peningkatan jumlah kasus penyakit Covid-19. Pengetahuan pasien Covid-19 dapat diartikan sebagai hasil tahu dari pasien mengenai penyakitnya, memahami penyakitnya, cara pencegahan, pengobatan dan komplikasinya (Sari \& Atiqoh, 2020). 
Salah satu cara untuk meningkatkan pengetahuan adalah melalui edukasi. Edukasi pada umumnya menggunakan metode ceramah (Arsyad, 2003). Agar materi edukasi dapat diterima semaksimal mungkin diperlukan suatu alat bantu mengajar (Amila, 2013). Video adalah alat bantu atau media edukasi yang dapat menunjukkan kembali gerakan-gerakan, pesan-pesan dengan menggunakan efek tertentu sehingga dapat memperkokoh proses pembelajaran dan dapat menarik perhatian penonton (Notoatmodjo, 2012)(Melina \& Soebiyanto, 2014)(HN, 2014). Selain metode ceramah, terdapat metode penyebaran leaflet yang dapat digunakan untuk edukasi. Leaflet merupakan media berbentuk selembaran kertas yang diberi gambar dan tulisan (biasanya lebih banyak berisi tulisan).

WHO menyarankan cara pencegahan dengan rajin mencuci tangan dengan sabun pada air yang mengalir, menjaga jarak dari orang saat bicara, jangan menyentuh wajah dengan tangan yang kotor. Juga disarankan untuk memakai masker serta menutup hidung dan mulut dengan tisu atau siku yang tertekuk ketika batuk (WHO, 2020). Adapun beberapa langkah yang pencegahan penyebaran covid-19 yang disampaikan oleh kementrian kesehatan yaitu : (a) selalu melakukan kebersihan tangan dengan menggunakan handsanitizer ataupun mencuci tangan menggunakan sabun di air mengalir, (b) jangan menyentuh mulut, mata atau hidung, (c) praktikan etika batuk dan bersin utamanya di tempat umum (d) gunakan masker saat keluar rumah, (e) terapkan prinsip jaga jarak (minimal 1 meter) (Kementrian Kesehatan, 2020).

Langkah-langkah preventif yang dilakukan tentunya harus sejalan dengan didukung oleh kontribusi media sosial sebagai edukasi masyarakat tentang Covid-19 di masa pandemi seperti yang terjadi sekarang ini. Melalui media sosial dapat diberikan tindakan-tindakan untuk mencegah penularan Covid-19 (Sampurno et al., 2020). Komunikasi media massa dalam hal ini adalah media sosial, merupakan komponen mendasar dari banyak strategi promosi kesehatan yang dirancang untuk mengubah perilaku risiko kesehatan (Alber et al., 2016).

Upaya yang bisa dilakukan dalam memberikan pengetahuan terhadap masyarakat luas terkait langkah-langkah pencegahan penyebaran covid-19 salah satunya yaitu melaui edukasi online. Edukasi online dapat menunjang proses pembelajaran menjadi salah satu hal formal dengan menggunakan teknologi (Bower, 2019). Proses dan metode belajar dengan jarak jauh menjadi kebiasaan baru yang mampu memberikan ringkasan melalui layar komputer atau smartphone (Fantini \& Tamba, 2020). Media sosial telah menjadi salah satu media untuk edukasi online, dimulai dari banyaknya informasi dan peluang terjadinya interaksi serta arahan untuk menuju pengembangan informasi ke dalam tautan lain. Hal tersebut menandakan bahwa selain keterkaitannya sebagai media hiburan, media sosial dapat dijadikan sebagai alternatif sumber jawaban untuk pertanyaan keseharian, termasuk info dan pertanyaan tentang Covid-19 (Sampurno et al., 2020). Penyampaian pesan edukasi secara online tidak hanya digunakan pada teknologi informasi saja, namun dapat juga digunakan pada bidang lainnya seperti kesehatan (Perera et al., 2017)

Edukasi online mengenai pencegahan covid-19 perlu dilakukan pada masyarakat tidak terkecuali di Kota Baubau. Berdasarkan hal tersebut, penelitian ini dilakukan untuk menganalisis efektivitas pemberian edukasi melalui media video dan leaflet terhadap tingkat pengetahuan pencegahan Covid-19 di Kota Baubau.

\section{METODE PENELITIAN}

Jenis penelitian ini adalah Quasi-Experimental Design dengan pendekatan nonequivalent control group pretest-posttest. Intervensi yang digunakan berupa pemberian edukasi secara online melalui media video, leaflet sekaligus video dan leaflet untuk meningkatkan pengetahuan masyarakat Kota Baubau tentang pencegahan covid-19. Video dan leaflet yang diberikan didesain oleh peneliti dengan merujuk pada Pedoman Pencegahan dan Pengendalian Coronavirus Disease (COVID-19) yang dikeluarkan oleh Kementerian Kesehatan RI Tahun 2020. Populasi pada penelitian adalah masyarakat Kota Baubau dengan populasi terjangkau pada masa pandemi Covid-19 yaitu peserta dari 54 group Whatsapp sebanyak 1600 orang. Dari populasi tersebut diperoleh sampel sebanyak 
120 orang. Sampel kemudian dibagi menjadi 3 kelompok berdasarkan jenis media edukasi yang diberikan yaitu media video, leaflet dan keduanya (video dan leaflet).

Sampel dipilih dengan menggunakan metode purposive sampling yang memenuhi kriteria inklusi. Adapun kriteria inklusi dalam penelitian ini yaitu menjadi peserta group Whatsapp, tinggal dan menetap di Kota Baubau serta bukan merupakan tenaga kesehatan. Sedangkan kriteria eksklusinya yaitu peserta tidak mengisi salah satu pretest atau posttest yang diberikan. Instrumen penelitian adalah kuesioner tentang tindakan pencegahan Covid-19 yang dibagikan secara online melalui link Google Form pada group Whatsapp. Edukasi diberikan selama enam hari yang terdiri dari informasi tentang pencegahan Covid-19, GERMAS (Gerakan Masyarakat Hidup Sehat), GEMAS (Gerakan Memakai Masker), PHBS (Perilaku Hidup Bersih dan Sehat), pembuatan imunomodulator dari bahan herbal serta cara penggunaan antiseptik dan desinfektan yang baik dan benar.

\section{HASIL DAN PEMBAHASAN}

\section{Karakteristik Responden}

Edukasi online merupakan salah satu cara yang digunakan untuk meningkatkan pengetahuan masyarakat khususnya tentang pentingnya menerapkan protokol kesehatan dan menjaga kesehatan diri, keluarga dan orang lain. Edukasi online dapat dilakukan dengan metode ceramah seperti webinar ataupun melalui media baik video dan leaflet. Video dan leaflet sebagai media edukasi yang diberikan pada penelitian ini berisi informasi tentang pencegahan Covid-19, GERMAS (Gerakan Masyarakat Hidup Sehat), GEMAS (Gerakan Menggunakan Masker), PHBS (Perilaku Hidup Bersih dan Sehat), pembuatan imunomodulator dari bahan herbal serta cara penggunaan antiseptik dan desinfektan yang diposting dan disebarkan melalui media sosial Whatsapp. Edukasi online ini dilaksanakan selama 6 hari dari tanggal 9-14 juni 2020, secara berturut-turut dimulai dari edukasi tentang Covid-19, GERMAS, GEMAS, PHBS, pembuatan imunomodulator serta cara penggunaan antiseptik dan desinfektan. Edukasi dilakukan secara online karena mempertimbangkan kondisi pandemi saat ini sehingga tidak memungkinkan untuk dilakukan secara offline.

Karakteristik responden berdasarkan jenis kelamin, umur dan pekerjaan dapat dilihat pada tabel 1. Berdasarkan jenis kelamin, laki-laki berjumlah 47 responden $(39,2 \%)$ sedangkan perempuan berjumlah 73 responden $(60,8 \%)$. Berdasarkan kelompok umur, responden didominasi oleh kelompok umur antara 20-24 tahun sebanyak 93 responden (77,5\%), sedangkan berdasarkan karakteristik pekerjaan didominasi oleh kelompok mahasiswa yaitu sebanyak 86 responden $(71,7 \%)$.

Tabel 2 menunjukkan pengetahuan masyarakat Kota Baubau tentang pencegahan Covid-19 berdasarkan media edukasi yang diberikan, diukur dengan menggunakan kuesioner melalui aplikasi google form. Pada saat pretest, nilai mean dan median paling tinggi dimiliki oleh kelompok media edukasi video sekaligus leaflet yaitu 19,63 dan 20,0. Demikian pula pada saat posttest, nilai mean dan median paling tinggi juga dimiliki oleh kelompok media edukasi video sekaligus leaflet yaitu 21,10 dan 22,0. Berdasarkan variasi data pada saat pretest, nilai yang paling kecil adalah kelompok media Leaflet saja sebesar $\pm 2,11$; begitupun pada saat posttest dengan nilai sebesar $\pm 1,80$. Nilai yang paling kecil saat pretest adalah pada kelompok media video saja yaitu 12,0 , begitupun pada saat posttest dengan nilai sebesar 9,0. Nilai maksimum tertinggi pada saat pretest adalah pada kelompok media video sekaligus leaflet dengan nilai 24,0 begitupun saat postest pada kelompok media video sekaligus leaflet dan video saja dengan nilai 25,0.

Uji normalitas dengan menggunakan Shapiro-Wilk menunjukkan bahwa data yang berdistribusi normal adalah pada kelompok pretest dengan media edukasi menggunakan Leaflet saja dan video sekaligus leaflet sehingga statistik deskriptif menggunakan nilai mean \pm standar deviasi. Sedangkan kelompok lain tidak berdistribusi normal sehingga statistik deksriptif menggunakan nilai median dan jangkauan (Min - Max). 
Tabel 1. Karakteristik Responden Berdasarkan Jenis Kelamin, Umur, dan Pekerjaan

\begin{tabular}{llcc}
\hline Uraian & \multicolumn{1}{c}{ Kategori } & $\begin{array}{c}\text { Jumlah } \\
\text { (Responden) }\end{array}$ & Persentase (\%) \\
\hline Jenis Kelamin & Laki-laki & 47 & 39,2 \\
& Perempuan & 73 & 60,8 \\
& Total & 120 & 100,0 \\
\hline Umur & 15-19 tahun & 8 & 6,7 \\
& 20-24 tahun & 93 & 77,5 \\
& 25-29 tahun & 8 & 6,7 \\
& 30-34 tahun & 6 & 5,0 \\
& 35-39 tahun & 1 & 0,8 \\
& 40-44 tahun & 1 & 0,8 \\
& 45-49 tahun & 2 & 1,7 \\
& 50-54 tahun & 1 & 0,8 \\
& Total & 120 & 100,0 \\
\hline Pekerjaan & Pegawai negeri & 4 & 3,3 \\
& Tentara / Polri & 2 & 1,7 \\
& Pegawai swasta & 4 & 3,3, \\
& Pedagang/ Wirausaha & 1 & 0,8 \\
& Nelayan & 1 & 0,8 \\
& Mahasiswa/i & 86 & 71,7 \\
& Lainnya & 22 & 18,3 \\
& Total & 120 & 100,0 \\
\hline
\end{tabular}

Tabel 2. Hasil Pretest dan Posttest Pengetahuan Responden berdasarkan Media Edukasi

\begin{tabular}{lcccccc}
\hline Media Edukasi & $\mathrm{N}$ & Mean & Median & Std.deviasi & Min - max & $\begin{array}{c}\text { Sig. } \\
\text { (normalitas) }\end{array}$ \\
\hline Pretest & & & & & & \\
\hline Leaflet & 40 & 18,83 & 19,0 & $\pm 2,11$ & $15,0-23,0$ & $0,073^{*}$ \\
\hline Video & 40 & 19,60 & 19,5 & $\pm 2,26$ & $12,0-23,0$ & 0,020 \\
\hline Video + Leaflet & 40 & 19,63 & 20,0 & $\pm 2,45$ & $13,0-24,0$ & $0,068^{*}$ \\
\hline Posttest & & & & & & \\
\hline Leaflet & 40 & 19,43 & 20,0 & $\pm 1,80$ & $16,0-22,0$ & 0,000 \\
\hline Video & 40 & 19,98 & 20,0 & $\pm 3,17$ & $9,0-25,0$ & 0,000 \\
\hline Video + Leaflet & 40 & 21,10 & 22,0 & $\pm 2,76$ & $16,0-25,0$ & 0,005 \\
\hline
\end{tabular}

* Berdistribusi normal menggunakan Uji Shapiro-wilk $(\alpha=0,05)$

Gambar 1 memperlihatkan gambaran pengetahuan masyarakat Kota Baubau tentang pencegahan penularan Covid-19 dengan menggunakan boxplot. Boxplot atau biasa disebut Box and Whisker Plot merupakan ringkasan distribusi sampel yang disajikan secara grafis yang bisa menggambarkan bentuk distribusi data (skewness), ukuran tendensi sentral (pemusatan) dan ukuran penyebaran (keragaman) data pengamatan. Bagian utama boxplot adalah kotak berbentuk persegi (Box) yang merupakan bidang yang menyajikan interquartile range (IQR), dimana $50 \%$ dari nilai data pengamatan terletak disana. Pada saat pretest dapat dilihat bahwa ketiga kelompok mempunyai gambaran IQR yang hampir sama sehingga baseline data berada pada kelompok yang sama. Berbeda pada saat posttest, sajian IQR berbeda pada setiap metode edukasi.

Garis hitam tebal di tengah kotak merupakan nilai median. Berdasarkan gambar 1 dapat diinterpretasikan bahwa sebaran data dan nilai median saat pretest hampir sama pada semua kelompok. Sedangkan pada saat posttest sebaran data terkecil pada kelompok media edukasi leaflet saja dan sebaran data terbesar yaitu pada kelompok media edukasi video sekaligus leaflet. 
Outlier adalah data observasi yang muncul dengan nilai-nilai ekstrim, baik secara univariat ataupun multivariat. Yang dimaksud dengan nilai-nilai ekstrim dalam observasi adalah nilai yang jauh atau beda sama sekali dengan sebagian besar nilai lain dalam kelompoknya. Pada Gambar 1 ditunjukkan oleh bundaran kecil diluar kotak. Nilai outlier terdapat pada kelompok pretest dengan kelompok media edukasi video saja dan kelompok video sekaligus leaflet. Pada saat posttest, terdapat data ekstrim yang dimiliki oleh kelompok media edukasi video yaitu data minimum pada kelompok tersebut dengan nilai 9.
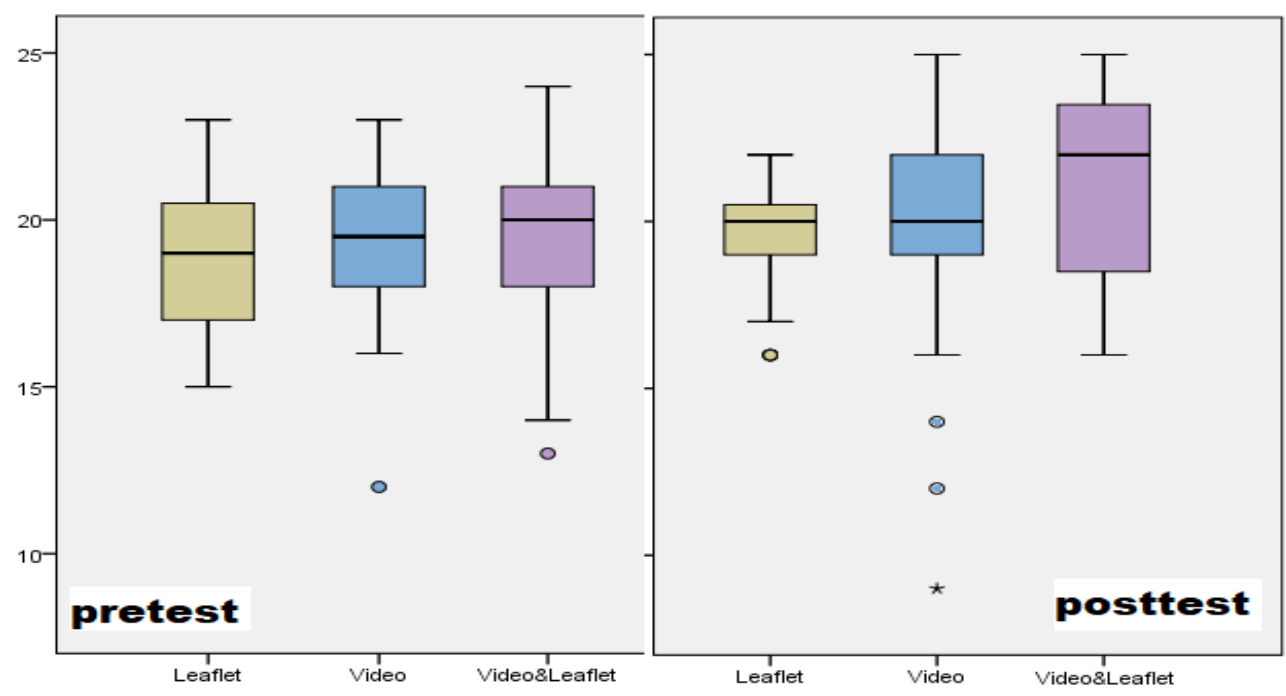

Gambar 1. Gambaran pengetahuan masyarakat kota Baubau menggunakan boxplot

Secara deskriptif, sebelum diberikan edukasi nilai rerata hampir sama yang menandakan bahwa baseline data penelitian ini sama. Dimana ketiga kelompok ini homogen. Sedangkan setelah diberikan edukasi, terjadi keberagaman data diantara ketiga metode. Hal ini juga ditunjukkan oleh nilai standar deviasi yang paling besar yaitu pada kelompok postest dengan edukasi video yang disebabkan oleh adanya nilai ekstrim yang jauh berbeda dengan nilai reratanya (tabel 2). Metode edukasi dengan memanfaatkan media online ini, tentunya menjadikan banyak hal yang tidak dapat terkontrol. Salah satunya, kurangnya partisipatif secara emosional dari peneliti karena tidak bertemu langsung atau sekedar menyampaikan manfaat dari tujuan penelitian ini. Sehingga masih ada kemungkinan, responden menjawab soal dengan asal-asalan.

Tabel 3. Perbedaan Pengetahuan Sebelum dan Sesudah Pemberian Edukasi Pencegahan COVID19 berdasarkan media edukasi

\begin{tabular}{cccc}
\hline Media Edukasi & $\begin{array}{c}\text { Pretest Median } \\
(\text { Min-Max })\end{array}$ & $\begin{array}{c}\text { Posttest Median } \\
(\text { Min-Max })\end{array}$ & P-value \\
\hline Leaflet & $18,83( \pm 2,11)$ & $20,0(16,0-22,0)$ & $0,045^{*}$ \\
\hline Video & $19,50(12,0-23,0)$ & $20,0(9,0-25,0)$ & 0,248 \\
\hline Video + Leaflet & $19,63( \pm 2,45)$ & $22,0(16,0-25,0)$ & $0,001^{*}$ \\
\hline
\end{tabular}

Ket: * uji signifikan dengan Wilcoxon $(\alpha=0,05)$

Dengan menggunakan uji wilcoxon, menunjukkan bahwa ada perbedaan pengetahuan responden antara sebelum dan sesudah diberi edukasi pencegahan covid-19 melalui media leaflet dimana nilai $\mathrm{P}=0,045 \leq \mathrm{a}=0,05$ dengan nilai median pada pretest yaitu 18,83 dan nilai median pada posttest yaitu 20,0 (tabel 3). Pada edukasi pencegahan covid-19 melalui video didapatkan nilai median pada pretest yaitu 19,5 , nilai median pada posttest yaitu 20,0 dan niai $\mathrm{P}=0,248 \geq \mathrm{a}=0,05$ yang berarti tidak ada perbedaan pengetahuan responden sebelum dan sesudah diberi edukasi. Sedangkan pada edukasi pencegahan covid-19 melalui video+leaflet didapatkan nilai median pada pretest 19,63, nilai median pada posttest 22,0 dan nilai $\mathrm{P}=0,001 \leq \mathrm{a}=0,05$ yang berarti ada perbedaan pengetahuan responden sebelum dan sesudah diberi edukasi. 
Berdasarkan hasil uji statistik dengan wilcoxon, ada perbedaan yang signifikan terhadap pengetahuan sebelum dan sesudah diberikan leaflet saja sebagai media edukasi online pencegahan Covid-19. Hasil penelitian ini sejalan dengan penelitian kasman (2017) bahwa penggunaan media leaflet dapat berpengaruh terhadap pengetahuan tentang bahaya merokok pada SDN 78 Sabrang Lor Mojosongo (Kasman et al., 2017). Selain itu, hasil penelitian oleh Muslikha dan Purwanti (2011) juga menunjukkan bahwa terdapat peningkatan pengetahuan ibu tentang ASI eksklusif dan dorongan ibu untuk menyusui secara eksklusif (Muslikha \& Purwanti, 2011).

Leaflet adalah sebuah media informasi yang telah dirangkai menjadi informasi yang sifatnnya ringkas dan jelas sehingga dapat memudahkan setiap orang untuk bisa memahami informasi yang telah diberikan. Informasi yang ada di dalam leaflet harus menggunakan tata bahasa yang mudah dipahami bagi setiap orang. Judul yang terdapat dalam leafletpun harus dibuat menarik serta dapat dipadukan dengan gambar - gambar yang berkaitan dengan isi leaflet. Kemudian isi yang ada dalam leaflet harus disesuaikan dengan sasaran yang akan diberikan intervensi (Yulianti et al., 2011). Tak hanya itu, media leaflet mempunyai keunggulan yaitu pada penyebaran secara online, tidak mempunyai kapasitas besar untuk mengunduh sehingga tidak membutuhkan paket data yang banyak karena dalam bentuk gambar. Keunggulan lainnya yaitu karena leaflet disebar secara digital maka setelah terunduh responden dapat melihat isinya secara mudah dan berkali-kali

Sedangkan media video saja tidak ditemukan ada perbedaan antara sebelum dan sesudah pemberian edukasi pencegahan COVID-19 pada grup WA yang disebar secara online. Hasil penelitian ini sejalan dengan penelitian Kasman (2017) yang menyebutkan bahwa tidak ada pengaruh penggunaan media video terhadap penngetahuan siswa SDN 78 Sabrang Lor Mojosongo tentang bahaya merokok (Kasman et al., 2017). Lain halnya dengan hasil penelitian oleh Igiany, dkk bahwa ada perbedaan antara sebelum dan sesudah penggunaan video dalam meningkatkan pengetahuan, sikap dan keterampilan ibu mencuci tangan memakai sabun (Igiany et al., 2016).

Metode yang terakhir adalah dengan menggunakan media edukasi penggunaan video sekaligus leaflet. Berdasarkan hasil dengan uji wilcoxon menunjukkan bahwa ada perbedaan yang signifikan terhadap peningkatan pengetahuan sebelum dan sesudah diberikan media edukasi tersebut. Penelitian ini sejalan dengan hasil Notoiswoyo (2014) bahwa VCD dan leaflet dapat digunakan sebagai media intervensi untuk meningkatkan pengetahuan, sikap, dan perilaku pencegahan kecelakaan lalu lintas sepeda motor yang efektif bagi siswa SLTA di Kota Bekasi. Hasil evaluasi terhadap siswa yang diintervensi menunjukan sebagian besar dari mereka menyatakan bahwa substansi media VCD dan leaflet, menarik dan komunikatif serta dapat meningkatkan sikap dan perilaku pencegahan kecelakaan sepeda motor (Notosiswoyo, 2014).

Informasi yang diberikan kepada responden dengan menggunakan media audio visual atau video dapat dimengerti karena setiap responden akan mudah mencermati jika terdapat gambar yang dapat dilihat dan suara yang dapat didengar. Dalam hal ini dianggap efisien dan praktis, video lebih bersifat mudah dipahami dan bisa di tayangankan berulang kali sehingga efektif untuk mengubah pandangan sasaran yang akan diintervensi (Igiany et al., 2016). Media video mengandalkan pendengaran dan penglihatan dari sasaran, dimana penggunaan audiovisual melibatkan semua alat indera, sehingga semakin banyak alat indera yang terlibat untuk menerima dan mengolah informasi, semakin besar kemungkinan isi informasi tersebut dapat dimengerti dan dipertahankan dalam ingatan, dan dengan efek gambar yang bergerak dan efek suara dapat memudahkan audiens memahami isi berita sehingga dapat menambah pengetahuan (Maulana et al., 2009). Namun kekurangan dari media ini yaitu pada penyebaran yang dilakukan secara online, sehingga membutuhkan kapasitas memori yang besar untuk mengunduhnya dan membutuhkan paket data yang lebih banyak dari leaflet, hal ini menyebabkan pesan yang terkandung dalam media video secara online tidak tersampaikan dengan baik ke responden.

Perbedaan pengetahuan sesudah pemberian edukasi pencegahan covid-19 antara media leaflet saja dan leaflet sekaligus video dapat dilihat pada table 4. Dengan menggunakan uji mann whitney didapatkan nilai $\mathrm{P}=0,002 \leq \mathrm{a}=0,05$, dimana dapat disimpulkan bahwa ada perbedaan pengaruh 
antara kelompok leaflet dan kelompok leaflet + video pada edukasi. Berdasarkan nilai median, perbedaan pengetahuan yang paling efektif adalah dengan media edukasi leaflet sekaligus video.

Tabel 4. Perbedaan Pengetahuan Sesudah Pemberian Edukasi Pencegahan Covid-19 Melalui Media Leaflet saja dan Leaflet sekaligus Video.

\begin{tabular}{ccc}
\hline Media Edukasi & Posttest & P-value $* *$ \\
\hline Leaflet & $20,0(16,0-22,0)$ & 0,002 \\
\hline Leaflet + Video & $22,0(16,0-25,0)$ & \\
\hline Ket: ${ }^{* *}$ uji signifikan dengan Mann-Whitney $(\alpha=0,05)$ &
\end{tabular}

Efektivitas terhadap metode edukasi ini disajikan pada tabel 4 dimana berdasarkan nilai median bahwa penggunaan leaflet sekaligus video lebih tinggi dibandingkan dengan penggunaan leaflet saja terhadap peningkatan pengetahuan Masyarakat Kota Baubau tentang pencegahan Covid-19. Hal ini dimungkinkan karena pada penggunaan dua media sekaligus (video dan leaflet), responden terpapar dua kali terhadap informasi yang diberikan. Berbeda halnya dengan penggunaan video saja, responden hanya terpapar satu kali.

Media edukasi online dapat memberikan dampak terhadap peningkatan pemahaman dan perubahan perilaku (Mulyani et al., 2020). Faktor-faktor yang mempengaruhi keberhasilan sosialisasi online yaitu faktor individu, penyajian materi video dan leaflet, pemilihan kata yang digunakan, visualisasi pada media leaflet dan video serta audio yang digunakan pada media video. Faktor individu yang dimaksud yaitu dari karakteristik sifat individu dalam memahami sebuah materi leaflet maupun video, kapasitas pemahaman orang tentunya berbeda-beda dan kecenderungan ketertarikan terhadap suatu materi yang diberikan juga berbeda-beda, ada yang lebih menyukai materi disajikan dalam bentuk tulisan, ada yang perlu ditambahkan visualisasi gambar bahkan ada yang lebih menyukai visualisasi gambar dan audionya. Materi dan pemilihan kata mempengaruhi keberhasilan sosialisasi karena apabila materi dan pemilihan kata yang digunakan terlalu rumit akan mempersulit masyarakat dalam memahami materi yang disajikan, selain itu visualisasi dan audio sangat mempengaruhi ketertarikan dalam melihat ataupun membaca media sosialisasi tersebut, visualisasi dan audio yang tidak sesuai akan menyebabkan masyarakat menjadi bosan sehingga tidak akan mencapai outcome sosialisasi yang diharapkan.

\section{KESIMPULAN}

Berdasarkan hasil penelitian ini dapat disimpulkan bahwa edukasi yang dilakukan secara online, efektif dalam meningkatkan pengetahuan masyarakat di Kota Baubau dalam pencegahan Covid-19 adalah dengan menggunakan media video sekaligus leaflet.

\section{DAFTAR PUSTAKA}

Arsyad, A. (2003). Media Pembelajaran. Jakarta: Grafinddo Persada.

Alber, J. M., Paige, S., Stellefson, M., \& Bernhardt, J. M. (2016). Social media Self-efficacy of Health Education specialists: training and organizational development implications. Health Promotion Practice, 17(6), 915-921.

Amila, L. E. (2013). Artikel Ilmiah Pengaruh Penyuluhan Menggunakan Metode Ceramah Dengan Media Audio Visual Terhadap Pengetahuan Remaja Tentang Narkoba Di SMA Negeri 1 Gomo Kecamatan Gomo Kabupaten Nias Selatan Tahun 2013. Universitas Sari Mutiara Indonesia.

Bower, M. (2019). Technology-mediated learning theory. British Journal of Educational Technology, 50(3), 1035-1048.

Chen, Nanshan; Zhou, Min; Dong, Xuan; Qu, Jieming; Gong, Fenghyun; Han, Yang; Qiu, Yang; 
Wang, Jingli; Liu, Ying; Wei, Yuan; Xia, J. (2020). Epidemiological and clinical characteristics of 99 cases 2019 novel coronavirus pneumonia in Wuhan, China: a descriptive study. 395(10223), 507-513.

COVID-19, G. T. P. P. (2020). Website Gugus Tugas Percepatan Penanganan COVID-19. Retrieved from https://covid19.go.id/

Fantini, E., \& Tamba, R. S. (2020). Mediamorfosis Edukasi Informal Online Melalui Platform Digital Sebagai Peluang Bisnis Baru. Majalah Ilmiah Bijak, 17(1), 114-127.

Hessen, M. T. (2020). Novel Coronavirus Information Center: Expert guidance and commentary.

HN, F. (2014). Pengaruh Penyuluhan Cuci Tangan menggunakan Media Video terhadap Keterampilan Cuci Tangan pada Siswa Sekolah Dasar Karya Tulis Ilmiah Program D IV Bidan Pendidik. Universitas Sebelas Maret.

Huang, Chaolin; Wang, Yeming; Li, Xingwang; Ren, Lili; Zhao, Jianping; Hu, Yi; Zhang, L. F., \& Guohui; Xu, Jiuyang; Gu, Xiaoying; Cheng, Z. (2020). Clinical features of patients infected with 2019 novel coronavirus in Wuhan, China.

Hui DS, I Azhar E, Madani TA, Ntoumi F, Kock R, Dar O, Ippolito G, Mchugh TD, M. Z., \& Drosten C, Zumla A, P. E. (2020). The continuing 2019-nCoV epidemic threat of novel coronaviruses to global health - The latest 2019 novel coronavirus outbreak in Wuhan, China. Int J Infect Dis.

Hui, D. S., Azhar, E. I., Madani, T. A., Ntoumi, F., Kock, R., Dar, O., ... \& Zumla, A. (2020). The continuing 2019-nCoV epidemic threat of novel coronaviruses to global health-The latest 2019 novel coronavirus outbreak in Wuhan, China. International Journal of Infectious Diseases, 91, 264-266.

Igiany, P. D., Sudargo, T., \& Widyatama, R. (2016). Efektivitas penggunaan video dan buku bergambar dalam meningkatkan pengetahuan, sikap, dan keterampilan ibu mencuci tangan memakai sabun. Berita Kedokteran Masyarakat, 32(3), 89-94.

Kasman, K., Noorhidayah, N., \& Persada, K. B. (2017). Studi Eksperimen Penggunaan Media Leaflet Dan Video Bahaya Merokok Pada Remaja. Jurnal Publikasi Kesehatan Masyarakat Indonesia, 4(2), 10-14. https://doi.org/10.20527/jpkmi.v4i2.3842

Kementrian Kesehatan. (2020). Pedoman COVID REV-4. Pedoman Pencegahan Dan Pengendalian Coronavirus Disease (COVID-19), 1(Revisi ke-4), 1-125.

Li, Q., Guan, X., Wu, P., Wang, X., Zhou, L., Tong, Y., .. Wong, J. Y. (2020). Early transmission dynamics in Wuhan, China, of novel coronavirus-infected pneumonia. New England Journal of Medicine.

Maulana, H., Heri, D., J. (2009). Promosi Kesehatan. Jakarta: EGC.

Melina F, Soebiyanto AA, W. H. (2014). Perbedaan Media Pembelajaran ( Leaflet Dan Video ) Terhadap Keterampilan Sadari Ditinjau Dari Motivasi. J Kesehat “ Samodra Ilmu, ” 05(02), $116-125$.

Mulyani, E. Y., Ummanah, N. A., \& Elvandari, M. (2020). Peningkatan Pengetahuan Mahasiswa Melalui Edukasi Online Gizi dan Imunitas Saat Pandemic Covid-19. 1(1), 70-78.

Muslikha, P., \& Purwanti, S. (2011). Peran Leaflet Asi Ekslusif Terhadap Pengetahuan Ibu Tentang Asi Ekslusif Dan Motivasi Untuk Menyusui Secara Ekslusif Di Bps Ny. Djuwedah Kebasen Kabupaten Banyumas. Djuwedah Kebasen Kabupaten Banyumas. Purwokerto: 
Akademi Kebidanan YLPP, 2(1).

Notoatmodjo S. (2012). Promosi Kesehatan dan Perilaku Kesehatan. Jakarta: Rhineka Cipta.

Notosiswoyo, M. (2014). Penggunaan VCD dan Leaflet untuk peningkatan pengetahuan, sikap, dan perilaku siswa dalam pencegahan kecelakaan sepeda motor. Kesmas: National Public Health Journal, 8(8), 373-379.

Perera, V., Mead, C., Buxner, S., Lopatto, D., Horodyskyj, L., Semken, S., \& Anbar, A. D. (2017). Students in fully online programs report more positive attitudes toward science than students in traditional, in-person programs. CBE—Life Sciences Education, 16(4), ar60.

Sampurno, M. B. T., Kusumandyoko, T. C., \& Islam, M. A. (2020). Budaya Media Sosial, Edukasi Masyarakat, dan Pandemi COVID-19. SALAM: Jurnal Sosial Dan Budaya Syar-I, 7(5). https://doi.org/10.15408/sjsbs.v7i5.15210

Sari, D. P., \& Atiqoh, N. S. (2020). Hubungan Antara Pengetahuan Masyarakat dengan Kepatuhan Penggunaan Masker Sebagai Upaya Pencegahan Penyakit Covid-19 Di Ngronggah. Jurnal Ilmiah Rekam Medis Dan Informatika Kesehatan, 10(1), 52-55.

satgas covid sultra. (2020). Instagram Satuan Tugas Covid Sulawesi Tenggara. Retrieved from https://www.instagram.com/p/CCDiRpuBrLz/?igshid=1jxuwnyud9v11

World Health Organization. (2020). Situation reports. : https://www.who.int/docs/defaultsource/coronaviruse/situation-reports/20200329-sitrep-69-covid-19.pdf?sfvrsn=8d6620fa_8.

Yan Bai, Lingsheng Yao, T. W. (2020). Presumed Asymptomatic Carrier Transmission of COVID-19. JAMA, 323(14), 1406-1407. Retrieved from https://jamanetwork.com/journals/jama/fullarticle/2762028

Yulianti D, Yudha KE, H. A. (2011). Promosi Kesehatan dalam Praktik Kebidanan. Jakarta: Buku Kedokteran EGC. 